\title{
NORdisk MuseumSFESTIVAL I STAVANGER - FORUM FOR UTSTILLINGSPROBLEMATIKK
}

\author{
Ase Enerstvedt
}

\section{Varen 1993 ble museer over bele Norden invitert til à delta i Nordisk}

Museumsfestival - en svensk idé som på grunn av samarbeidet med Arkeologisk museum i Stavanger (AmS) - ble lagt til Stavanger. Planen var at festivalen skulle gå på omgang $i$ de nordiske land, og avholdes hvert annet år. Av flere grunner ble det imidlertid ingen ny festival for i 1998. Og igjen var det Stavanger og AmS som var vertskap.

Arkeolog Gundula Adolfsson og försteantikvarie Inga Lundström hadde samarbeidet tidligere om flere utstillingsprosjekt, og sistnevnte hadde gjort seg bemerket $\mathrm{i}$ Norge med gode utstillinger både ved Bryggen museum i Bergen og Arkeologisk museum i Stavanger. I Stavanger var det særlig avdelingsleder Oddveig Foldøy som var deres samarbeidspartner. Gjennom samarbeidet vokste tanken fram hos Adolfsson og Lundström om en festival der museumsfolk kunne samles om interessen for utstillingen som formidlingsform. Tanken ble mottatt med velvilje ved Arkeologisk museum og utviklet videre i samarbeid med Oddveig Foldøy. Gjennom diskusjoner og grundig planlegging, ble ideene omsatt $\mathrm{i}$ praksis for første gang i 1993.

\section{FESTIVAL SOM MØTEFORM}

Hva er nytt ved dette tiltaket? Har ikke museene tilstrekkelig mange anledninger til å møtes? I Norge, i Norden og internasjonalt finnes organisasjoner som hvert år har store samlinger der det arrangeres utstillinger, holdes seminarer og foredrag og der det diskuteres fagspørsmål. Hva er så nytt ved Nordisk Museumsfestival, og er det bruk for enda et jevnlig tilbakevendende arrangement for museumsfolk?

La oss se nærmere på hva som skiller festivalen fra alt annet som foregår innen dette området: For det forste er dette en begivenhet som konsentrerer all interesse om utstillingsproblematikk. Museer og enkeltpersoner inviteres til å delta med en egen utstilling - rettere: en utstillingsidé. Så vidt jeg vet, er dette det eneste stedet $\mathrm{i}$ Europa - kanskje internasjonalt - der flere 
kulturhistoriske - og naturvitenskapelige! - utstillinger eksponeres samtidig, slik at utøverne får anledning til å studere hverandres arbeid. I tillegg vurderes de av en jury og har håp om en offisiell anerkjennelse. Det utdeles to likestilte priser, en for teknisk løsning og en for idéinnhold. Det deles også ut ett eller flere diplom som oppmuntring til gode prosjekter.

For det andre er festivalen et forum for originale og spennende diskusjoner, med innlegg av inviterte personer, blant annet noen som til daglig står utenfor museumsarbeidet, og kan se på virksomheten med nye og friske øyne. Det gis god tid til uformelle samtaler, og felles lunsj og middag gir den rette festivalstemningen.

Det tredje punktet er at det $-\mathrm{i}$ hvert fall inntil videre - synes som om festivalen skal avholdes på samme sted hver gang. Dermed oppnås kontinuitet og rutine som både administrasjon og deltakere har fordeler av. Med en fast rutine i bunnen, kan festivalledelsen uten store problem legge inn endringer som gjør hver festival ny og annerledes for deltakerne, samtidig med at man har kontroll med de store linjene. Derved unngår man mange av de forviklinger og kjedelige misforståelser som ellers lett oppstår når uerfarne arrangører har ansvaret. Det er også sannsynlig at en festival som holdes på samme sted gang etter gang, vil bli et begrep hos publikum. Det har vi erfaring for fra andre kulturfestivaler.

\section{HENSIKTEN MED EN MUSEUMSFESTIVAL}

Inga Lundström, den ene av de svenske initiativtakerne, summerer opphavskvinnenes tanker i disse setningene:
Festivalen skall bidra till att

- inspirera till att omsätta utställningsideer till utställning;

- öka lusten att experimentera med nya former och nya innehåll;

- höja kompetensen och professionaliteten i utställningsarbetet;

- öppna kontaktvägar mellan museer och enskilda producenter;

- göra museiutställningen till ett mera dynamiskt medium.

Har de to festivalene som til nå har vært avholdt, kunnet bidra til å oppfylle ønskene i denne programerklæringen? Hvordan skal festivalene utformes for å kunne skape en utvikling i museenes utstillingsvirksomhet? La oss se litt på hvordan det til nå har vært, og la oss ta opp diskusjonen om resultat og fremtidig virksomhet.

\section{EN VURDERING AV DE TO FESTIVALENE}

Mens festivalen i 1993 hadde temaet $A$ sprenge grenser som de deltakende utstillerne kunne fabulere over, hadde 1998-festivalen det meget aktuelle temaet Venner og fiender.

En riktig vakker 1993-rapport med ryddig layout viser seg dessverre å mangle omtale av festivalens hovedtema! Ingen av arrangørene har tatt opp dette i sine innledninger. Da undertegnede skulle friske på hukommelsen og fant fram katalogen, var det umulig å finne igjen mottoet for festivalen. En liten forglemmelse som vi neppe opplever igjen. Kanskje skyldes forglemmelsen at mottoet den gangen først og fremst var et hjelpemiddel for å sette fart på fantasien hos den som hadde lyst til å delta, og ennå ikke hadde valgt tema. 
Det var også adgang til å delta med andre utstillinger.

Det var atskillig større oppslutning om festivalen i 1993 enn i 1998. Det kan skyldes at initiativtakerne kanskje brukte en litt annen fremgangsmåte for å markedsføre festivalen. Det kan også skyldes at museumsverdenen $\mathrm{i}$ det store og hele ikke oppfattet at dette var noe annet enn en konferanse. Dette bør vektlegges ved senere festivaler. Den første festivalen og utstillingene ble holdt i Stavangers nye kulturhus - Sølvberget - midt i sentrum. De fleste utstillerne fikk plass i den store, åpne hovedsalen, men noen måtte nøye seg med et mørkt rom uten vinduer i underetasjen. Det er ikke tvil om at dette skadet deres sak. Hva som ikke den gang var ordnet på forhånd, men som nå var rettet opp, var hvor utstillingsbidragene skulle plasseres. Festivalledelsen hadde fornuftig nok begge ganger gitt deltakerne en ramme for hvor stor plass de hadde å utfolde seg på.

Plasseringen av utstillingsmodellene i AmS i 1998 var ikke helt vellykket. AmS brukte et vindusløst lokale i underetasjen. Vanligvis er det å foretrekke at utstillingsrom er vindusløse, uten søyler og framspring og tunge takkonstruksjoner. Men helt strikt gjelder dette først og fremst for en helhetlig utstilling der det skal skapes en illusjon. I en festivalsituasjon, der mange forskjellige ideer og mange forskjellige løsninger stilles ved siden av hverandre uten hensyn til estetikk og helhet, må det være både armslag og gjerne dagslys. Det er en fordel å ha et stort, åpent rom til den slags utstillinger. Den som ønsker å presentere sitt bidrag i mystisk mørke, har alle slags tekniske hjelpemidler til rådighet. Utstillerne fra Tromsø Museum var i 1998 et typisk eksempel på dette. Deres løsning var etter min og mange andres mening den beste på utstillingen - kanskje både teknisk og idémessig. De hadde brukt sine tildelte kvadratmetere til å sette opp vegger av et hvitt tekstil/plastmateriale og slapp inn bare noen fă tilskuere av gangen. Inne i "teltet" lot de oss oppleve hvordan bruken av Tv-skjermer i utstillinger hyller oss inn i et uryddig flimmer av farger og former og trekker oppmerksomheten bort fra enhver gjenstand ellers i rommet. $\mathrm{Og}$ når vi kommer ut fra en slik utstilling, er vi forvirret og urolig, har opplevet ett eller annet, men husker ikke hva vi har sett. En original idé - å uttrykke en påstand, formidle en mening gjennom en utstilling uten bruk av trykte ord, bare ved hjelp av visuelle hjelpemidler. Minimalisme og syntese!

Mottoet - eller temaet - «Venner og fiender" som festivalen dreide seg om i 1998, var behørig tatt opp av alle utstillerne. Mens festivaldeltakerne i 1993 hadde stått helt fritt $\mathrm{i}$ forhold til temaet, var så godt som alle deltakerne i 1998 fenget av hovedideen. Det er kanskje også en av grunnene til at det var færre deltakere i 1998. Hvis man ikke allerede har på trappene en utstilling som kan presses inn $\mathrm{i}$ skjemaet, vil det nok føles og erfares som et ork å gi seg i kast med en utstillingsidé som ikke er ens egen. Til gjengjeld hadde de som deltok i 1998 gått alvorlig inn for oppgaven og fordypet seg i temaet. Tromsø Museums representanter erklærte for eksempel klart at deres bidrag var et ledd i kampen mot hva de så som alle gode utstillingers fiende: den overdrevne bruken av teknikk - og da først og fremst fjernsynsskjermene. Vinnerutkastet - for beste idé - gikk til Ryfylkemuseet som 
98 samarbeidet med jugoslaviske flyktninger om en utstilling som tok opp flyktningenes liv i Norge, med bare en kort henvisning til krigen de hadde flyktet fra. Museet hadde bygget en modell av utstillingslokalene og hadde nok en av de ryddigste og mest gjennomarbeidede presentasjonene. Temaet kunne i utstillingen fra Ryfylkemuseet gjenfinnes på flere plan. Ett plan besto av utstillernes bakgrunn: jugoslavene som deltok, hadde i Jugoslavia tilhørt ulike krigførende parter. I Norge samarbeidet de om en utstilling om felles erfaringer. Et annet plan var bevisstheten om fremmedfiendtligheten som finnes blant nordmenn. Hovedtemaet i utstillingen viser hvor uklare grenser kan være hvordan flyktninger møtes av problemer og regler, forordninger og byråkratiske irrganger $\mathrm{i}$ et land der de verken forstår språk eller kultur, - møter de venner eller fiender?

Likevel er kanskje ikke ideen helt original. Ett av de andre deltakermuseene har flyktninger både som medarbeidere og som tema, som målsetting for museet. Alt arbeid, alle utstillinger i dette museet dreier seg om å formidle flyktningenes kultur til nordmenn og vice versa. Heller ikke utstillingsløsningen var spesielt original. Vegger som skulle gi publikum en opplevelse av å bevege seg gjennom en labyrint $\mathrm{i}$ utstillingen, har vært brukt i flere utstillinger i Norden. Jeg kan i farten huske to bare i løpet av de siste årene.

Men sett under ett var dette en utstilling som fortjente oppmerksomhet. Presentasjonen var profesjonell og godt gjennomført - en modell med kvalitet, og museets leder hadde selv sett det betydningsfulle i å være tilstede ved festivalen, og presenterte selv utstillingsideen. Samtidig vet vi at utstillingen vil bli en realitet. Trass $\mathrm{i}$ at temaet kan være mer kontroversielt enn hva en utenforstående uten videre kan forstå.

Utstillingsideen som fikk prisen for beste tekniske løsning, gikk til to meget unge og tiltalende forskere ved Arkeologiska Institutionen, Universitetet i Stockholm. De hadde fått statlige midler til å lage en utstilling om fremmedfiendtlighet, og hadde valgt å bygge utstillingen rundt «samhälls-, makt- och identitetsteori ... dvs strukturer som är komplexa, mångfasetterade, delvis splittrade och motsägelsefulla.» Utstillingen skulle vise de sosiale og kulturelle sammenhengene mellom menneskers identitetsopplevelse og det samfunnsmessige, «strukturerande maktspelet». Den skriftlige redegjørelsen for utstillingsideen er tungt samfunnsteoretisk, og mer interessant enn den tekniske løsningen. Presentasjonen var iklke særlig profesjonell: Fire-fem ark som var revet ut av en notatblokk i A4-format var festet på veggen med tegnestifter eller tape. På arkene var tegnet amatørmessige konstruksjoner av rektangulære og runde søyler. På spørsmål om figurene var speil der publikum skulle se seg selv, om det var malerier, tredimensjonale figurer eller hva, svarte utstillerne at det hadde de ikke klart for seg ennå, og at de egentlig hadde stoppet prosjektet, fordi de ikke klarte å løse problemene. Utstillerne burde kanskje heller fătt prisen for en god idé?

\section{HVA ER EN FESTIVAL I MOTSETNING TIL EN KONFERANSE?}

Som navnet sier, er festivalen en "festlighet». Det er en anledning for en yrkesgruppe til å feire seg selv og sitt virke. På 
samme måte som filmkunstnere møtes for å vise hverandre - og verden - sine siste verk, kan museumsfolk vise hverandre sine verk: utstillingene som er museenes fornemste formidlingsmedium. Ved en festival skal juryen hovedsakelig være valgt blant utøvere, og prisutdelingen er den mest festpregete hendelsen i løpet av festivalen - kronen på verket - som fyrverkeriet på nyttårsaften. Ris og ros er i løpet av festivaldagene utdelt av kritikere og publikum som ser og diskuterer, skriver i aviser og forteller i radio og TV. Ved frokostbord, lunsjbord, middagsbord og på nachspiel, for ikke å snakke om over alle kaffekoppene i løpet av dagen, blir bidragene gjennomdrøftet av alle som er tilstede. Det gjettes og legges fram argumenter for hvilke bidrag man tror vil vinne. Det er her de faglige kommentarene blir luftet, og det er også her man kan oppdage publikums reaksjoner. Festivalen aktiviserer alle. Når juryen så til slutt lar dommen falle, kommer $\mathrm{i}$ og for seg alle ut av det med "palmer i hendene». Ikke bare de som făr priser, for bare det å ha vært med og ha fått anledning til å la en større forsamling få se ens arbeid, er en glede og ære. Prisvinnerne høster ære og berømmelse, men alle som har deltatt, har hatt utbytte av festivalen. Også publikum.

Årets festival hadde et seminarinnslag som etter undertegnedes mening tok for mye tid. Det var interessante foredrag, men konferansepreget ble for sterkt. Ett foredrag pr dag av en stor «kanon» kan være et trekkplaster. Men for øvrig skal tiden brukes til å studere og diskutere utstillingsbidragene og knytte kontakter. Kanskje kan det føre til samarbeid om nye og spennende utstillingsideer - blant annet til neste festival.
Den Nordiske Museumsfestivalen er et nyttig og viktig tiltak for de nordiske museenes kontakt og samarbeid. Derfor er det å ønske at også "Stavangerfestivalen" med tiden vil passe inn i det beskrevne mønsteret. Kan vi håpe at det som skjer vil bli omtalt mer, og at utstillingsideene blir anmeldt og formidlet på samme måte som når det er filmfestival i Haugesund? Den som deltar med utstillingsideer må være forberedt på både god og dårlig kritikk, en erfaring som museumsfolk ikke er vant til. Når får museene kritikk for sine utstillinger? Skuespillere, forfattere, malere, musikere - alle må fra deres aller første skritt på yrkesveien finne seg i å bli bedømt og kritisert. Dette er av betydning for innsatsen. Når en vet at ens arbeid blir gjort til gjenstand for en seriøs vurdering, skriftlig dokumentert, vil en anstrenge seg enda litt mer. Man kan lære av kritikk, være enig eller uenig i øyeblikket, men det som sies, legges på minnet.

\section{EN FESTIVALJURYS OPPGAVE}

For mange av deltakerne på museumsfestivalen i 1998, ble det oppfattet som om juryen var litt på villspor i forståelsen av sitt mandat. Ved enhver annen festival går man enten direkte på vinnerne og forteller om deres utmerkete innsats, eller det er flere nominerte som likeledes blir behørig rost. Når en av dem velges, er det som "primus inter pares». De øvrige bidragene nevnes ikke. For dem er det «folkedomstolen» og "kannestøperne» som råder banen både før og etter juryens avgjørelse.

Ved 1998-festivalen ble hvert eneste bidrag gjennomgått av jurymedlemmene fra talerstolen, og forhold som juryen fant negative, ble trukket fram. I stedet for at 
100 prisutdelingen skulle bli en storartet festavslutning, satt storparten av deltakerne igjen med en følelse av å ha vært oppe til eksamen - og strøket. Det er ikke i en slik sinnsstemning man skal forlate en festival. Alle kan akseptere at de ikke gikk til topps i konkurransen, men ingen skal behøve å få sine feil servert ved festens høydepunkt. Det er ikke uten grunn at begrepet "festtaler» finnes.

Selvfølgelig skal utstillerne tåle kritikk, men ikke der og da. Publikum kan være uenig med juryen i valget av prisvinnere, men må akseptere valget og bøye seg for kriteriene som juryen har lagt til grunn for sitt valg. Men hvis juryen gir seg til å trekke fram hvilke "feil» de har funnet hos alle dem som ikke vant, da stiller de seg selv til for hugg. Juryen behøver ikke forsvare sitt valg. Den er suveren. Og det er både udiplomatisk og krenkende å trekke fram negative sider under den store festen. Da opphører juryens dom å være «ufeilbarlig». Det er lett for et uenig publikum å finne at valget er tatt på et sviktende grunnlag. Juryen gir sine kritikere ammunisjon.

Naturligvis var det mange som var uenige i 1998-juryens dom, men det vil det alltid være ved prisutdelinger, og er bare et tegn på at folk er interessert og har satt seg inn i emnet. Men man kan undres over juryens tankebaner, når de tillater seg å si at utstillingsideen som fikk prisen for teknisk løsning, var den eneste som hadde forsøkt å fremstille et abstrakt motiv som tredimensjonal utstilling. Det var nettopp dette Tromsø Museum hadde gjort - og lykkes med. Riktignok var det en annen form for abstraksjon som ble demonstrert her enn i prisvinnerutkastet, men like fullt en abstraksjon. Dessverre foreligger ikke juryens dom skriftlig, slik at når dette nev- nes, bygger det på egen tilstedeværelse og hukommelse.

Stavanger Museums utstilling som var et originalt og morsomt utkast til en framstilling av menneskets forhold til ulven, ble kritisert fordi det ved inngangen ville bli tilbudt publikum å ta på seg en ulvemaske og oppleve utstillingen "som ulv». At man også kunne få prøve å være ulven i bestemors seng og utveksle replikker med en talende Rødhettedukke, "kunne kanskje fungere for barn». Flere av tilhørerne fikk inntrykk av at juryen oppfattet utstillingen som en "barneutstilling», og derfor mindre betydningsfull. I våre dager skal man vokte seg vel for å innta en slik holdning. Barn er i ferd med å bli tatt mer og mer hensyn til på mange av kulturens områder. Kanskje de sidene som ble ansett som "barnslige», var festivalens mest avanserte utstillingsideer! For øvrig var dette en utstilling som var lekkert presentert og gjennomarbeidet i sin form. Den var også tilstrekkelig "actionpreget" til å tiltrekke seg både tøff ungdom og ivrige ulvehatere og saueeiere - altså et nytt publikum.

De utstillingsbidragene som ikke vant, fikk alle en mer eller mindre ubehagelig dom, som utstillerne nok kunne likt å diskutere. Men en omtale som mange ble rystet over, var det som ble uttalt om Glomdalsmuseets utstilling om taternes liv og skjebne. Alle utstillere hadde levert en skriftlig redegjørelse for intensjonen med utstillingen. Så også Glomdalsmuseet som har opprettet et dokumentasjons- og formidlingssenter for romanikultur. Sammen med modellen som viser hele museumsbygget der utstillingen bare er en del, fulgte også en brosjyre som forteller om Romanifolkets Landsforening og om kultursenteret og museet. 
På grunn av reaksjoner fra Glomdalsmuseet på juryens uttalelser, og på grunn av en henvendelse fra Norsk Museumsutvikling, foreligger juryens uttalelse skriftlig om akkurat dette bidraget. Som tilhører ble man først og fremst slått av juryens uttalelse om at utstillingen fremsto som "klaustrofobisk» tettpakket av elementer og oppbygninger, og at den sto $\mathrm{i}$ motsetning til den åpne arkitekturen den var plassert i. Samtidig ble det sagt at temaet - et frihetshungrende folk - egnet seg dårlig som utstillingstema innendørs. Når man så leser hva juryen har skrevet, må man noe tvilende innrømme at man kan ha omtolket juryens mer poetiske utsagn om at "I stedet for at arbejde med arkitekturen og skabe et frit rum, hvor alt kan ske, sætter udstillingen de frie fugle i bur med et æstetisk greb der forvandles til et overgreb på en egenartet arkitektonisk ramme og i værste fald ender som en forgriben sig på en skrøbelig og egenartet kultur." Hva man sitter igjen med etter dette, er likevel at det er et sterkt forlangende at en utstiller skal ta større hensyn til arkitekturen - som sett fra brukerens synspunkt er emballasjen - enn til temaet for utstillingen. Museumsfolk har altfor ofte problemer med å skape gode utstillinger på tross $a v$ umulig arkitektur.

Hadde jurymedlemmene tatt dette opp i diskusjoner etter festivalen, hadde de stått fritt til det, og det er også interessante synspunkter de har. Blant annet mener juryen at utstillingen "vægter vore positive fordomme», og at utstillerne har tatt for seg «et folk der ikke ligefrem kan siges at have fremtiden for sig". Begge deler kontroversielle påstander som burde vekke både museumsfolk og andre til debatt. Kanskje juryen har rett? Eller har den selv vært preget av fordommer? I følgeskrivet som undertegnede har fătt anledning til å se, skriver juryformannen at juryen så seg selv som «et instrument for at få i gang den hårdt tiltrængte debat om museumsudstillinger», og "Vi trænger debat i udstillingsarbejde, og vi trænger at blive modsagt. Det kan tvinge os til at gå i os selv og udvikle mer nuancerede syn.»

Disse uttalelsene er vi mange museumsfolk som er enige i, men det er uansett ikke en jurys oppgave som jury. Velkommen i debatten etter festivalen!

\section{FESTIVALENS FRAMTID}

Det hadde vært å ønske at flere av de store museene hadde deltatt på festivalen. Hvor var Norsk Folkemuseum og De Sandvigske Samlinger? Hvor var Bergensmuseene, Hordalandsmuseene? Nordiska Museet og Nasjonalmuseet ? Hvor var de finske museene? Og hva med Island?

Føles festivalen ennå for liten og ubetydelig? Det kan ikke være plasseringen som spiller en rolle? Bergen har et verdenskjent festspillarrangement, og det er ingen som lar være å reise dit fordi byen ligger på Norges vestkyst. I våre dager finnes det vel neppe noe sted som kan regnes som «utkant»?

Museumsfestivalen fortjener å få mange flere deltakere neste gang. Det er å håpe at utstillingsrommet igjen må bli stort og lyst, og at aviser og tidsskrifter vil koste på seg å sende noen som går seriøst inn for oppgaven å vurdere utstillingsideene og omtale foredragene. Det er ikke nok at en og annen velvillig "hoffreporter" stikker innom og skriver om museumsvirksomheten som et festlig fritids- og hobbytiltak. Både fylkesmann Tora Aaslands åpning- 
Åse ENERSTVEDT

102 stale og tale ved prisutdelingen, samt foredragene av antropologen Thomas Hylland-Eriksen og scenografen Rolf Alme inneholdt ord og tanker som burde komme også andre enn museumsfolk til gode.

Museumsfestivalens "primus motor», avdelingsleder ved AmS, Oddveig Foldøy, har et klart syn på hvorfor hun er villig til å påta seg arrangementsansvaret for en toårig tilbakevendende nordisk museumsfestival i Stavanger. Hun sier at festivalens hovedidé er utstillingene, og at festivalen er nødvendig fordi det er dyrt å lage utstillinger, men her kan man få prøvd ut sine ideer, få dem vurdert og diskutert, forkaste dem eller forbedre dem. Og forhåpentligvis sette dem ut $\mathrm{i}$ livet. Det andre viktige poenget ved en slik museumsfestival som kanskje til og med kunne hatt undertittelen «utstillingsfestival» - er at det å lage utstillinger gir liten prestisje i museumskretser, og at festivalen kanskje kan bidra til å heve denne siden av museumsvirksomheten. Det nordiske perspektivet er viktig, for deltakerne kan her komme utenfor sin egen lille andedam og derved se sitt eget arbeid i forhold til et større område - hele det øvrige Norden. Oddveig Foldøy stiller et enkelt spørsmål som viser seg slett ikke å være så enkelt: Hva er en museumsutstilling? Og hva vil vi med det kulturhistoriske materialet? Det kan holdes mange festivaler omkring dette emnet, og spørsmålene blir da også stilt $\mathrm{i}$ forbindelse med de forskjellige temaene som ellers tas opp. Det er viktige spørsmål, grunnleggende spørsmål som bør belyses igjen og igjen, og hvis ulike svar er avgjørende for hvilket inntrykk den enkelte utstilling og det enkelte museum gir publikum.
Ikke bare ledelsen ved AmS, men også Stavanger kommune og Rogaland fylkeskommune har forstått betydningen av museumsfestivalen. Fylkeskommunen er medarrangør av festivalen, og har i tillegg gitt økonomisk bidrag til Rogalandsmuseer som ville stille med utstillingsideer, og de fikk da også uttelling denne gangen, ved at ett av museene som hadde fätt bidrag, stakk av med hovedprisen. Stavanger kommune inviterte alle festivaldeltakerne til en lekker lunsj i Børsen den siste dagen, en avslutning som gav deltakerne en oppmuntrende følelse av at festivalen oppfattes som betydningsfull for Stavanger, at museene settes pris på, og at arbeidet den enkelte gjør, er viktig.

\section{EPILOG}

Som avslutning skal vi igjen se på initiativtakeren Inga Lundströms programerklæring:

Festivalen skall bidra till att

- inspirera till att omsätta utställningsideer till utställning;

- öka lusten att exsperimentera med nya former och nya innehåll;

- höja kompetensen och professionaliteten i utställningsarbetet;

- öppna kontaktvägar mellan museer och enskilda producenter;

- göra museiutställningen till ett mera dynamiskt medium.

Kan man si at de to festivalene har bidratt til noe av dette? Med hensyn til det første punktet, omsette utstillingsideer til utstilling, er det mulig at prisvinnerne har fått så stor inspirasjon og oppbakking gjennom festivalen og anerkjennelsen de 
har oppnådd, at de vil kunne gjennomføre ideene i praksis. Men det viktigste er kanskje at deltakerne har lært noen knep og finesser av de andre, noe de kan ta med seg hjem og slik gjøre arbeidet lettere ved neste utstilling.

Det er utvilsomt noen som, etter å ha sett de andre bidragene, er blitt litt modigere, og våger å kaste seg ut med nye formløsninger for utstillingsarbeidet, men hovedinntrykket var likevel etter de to festivalene at de virkelig eksperimentelle utstillingene manglet foreløpig.

Innholdsmessig var kanskje ikke utstillingsideene verken i 1993 eller 1998 særlig dristige og nyskapende. Der må jeg gi juryen i 1998 rett når den hevder at de kulturhistoriske museene unngår konfrontasjoner i utstillingene. Temaene blir ufarliggjort. Dette er kanskje noe å tenke på for fremtidige festivaldeltakere. Kast dere ut i samfunnsdebatten ved hjelp av utstillingene! Det er gjennom dem museene fungerer. Det er utstillingene som for publikum er museet, og det er gjennom dem museene kan få oppmerksomhet. Det kan jo være at i en tid da publikum overfores med "action", både i nyhetssendingene, $\mathrm{i}$ underholdningen og i kunsten, er museenes fredelige måte å beskrive tilværelsen på, ikke så interessant å skrive om for våre dagers journalister. $\mathrm{Og}$ hvis mange oppfatter museene som meditasjonssteder, vil de fleste ha dem for seg selv i fred og ro, og er glad for at det fremdeles finnes steder uten hesblesende jag. Hvis det er slik museene fungerer, har de kanskje på den måten en betydningsfull rolle i samfunnet. Men vil museenes ansatte ha det slik? Når Inga Lundström håper at museumsfestivalen skal bidra til å høyne profesjonaliteten og gjøre museene mer dynamiske, er det fordi hun ønsker at de skal bli mer tydelige som deltakere i samfunnsdebatten.

Vi skal bare ha klart for oss at en del kanskje en større del enn vi aner - av publikum, er fornøyd med museene slik de er i dag. Flere av debattantene (som ikke selv var museumsfolk) nevnte at de satte pris på museenes stillferdige presentasjonsform. De anså museene som inspirasjonskilder og steder der de i behagelig fred kunne hente ideer til sitt eget arbeid. En arkitekt repliserte irritert til undertegnedes sukk om for liten oppmerksomhet for museene i media, at det samme gjaldt arkitektur, så en resignert tanke er: slik er kanskje kulturens lodd. Da er det betimelig med et spørsmål: Er det behov for større oppmerksomhet? Ja, jeg tror det. Først og fremst til fordel for den delen av befolkningen som ennå ikke har oppdaget nytten og gleden ved å oppleve en utstilling $\mathrm{i}$ et kulturhistorisk museum, men også fordi det nok vil heve profesjonaliteten og dermed kvaliteten på utstillingene.

Hva en kunne håpe, var at deltakerne på Nordisk Museumsfestival gjennom sitt møte med utstillinger i denne formen, og gjennom flere dagers konsentrasjon om emnet, vil bli mer bevisst i sine formidlingsbestrebelser, og oppleve et behov for å møtes igjen for videre drøftinger. Derfor ønsker jeg Museumsfestivalen i Stavanger et langt liv og at den må bli et begrep for utstillere, museumsfolk som ønsker å se hva andre gjør og kanskje delta selv en annen gang, for publikum for øvrig - og gjerne interesserte anmeldere fra ulike media. 
Ase Enerstredt

104

SUMMARY

The Nordic Museums Festival

- a forum for debate about exhibitions

In spring 1993 Nordic museums were invited to participate in "Nordisk Museumsfestival» (The Nordic Museums Festival), a Swedish idea, created in cooperation between Gundula Adolfsson and Inga Lundström from Sweden, and AmS (Arkeologisk Museum in Stavanger).

The first festival was held in Stavanger, Norway. The original plan was that in future different Nordic museums would take on the arrangement. This proved difficult for many reasons and finally, in the spring of 1998, AmS once again took responsibility for arranging the festival. In Scandinavia, this is a new and different form of museum activity. Museum workers are used to meetings, seminars and conferences, but the festival is a strange form. For trhat reason The Nordic Museum Festival had some minor faults, such as the jury who chose the prizewinner not quite knowing their duty, or the program being much too similar to a conference. One of the tasks of the festival is to create better communication between museum workers and museum visitors, media workers, and bureaucrats handling museum finances and politicies. Visiting the festival exhibitions, listening to the talks and getting the opportunity "to get a look behind the scenes" may afford a better understanding of the role museums can play in a modern society. But the main task is to give museum workers the chance to try out exhibition ideas as models on a smaller scale, discuss ideas, and concentrate for a few days on the art of creating exhibitions. The majority of Nordic museums lack the staff to keep up with the demands of modern exhibition methods and theories. Getting together every second year, exchanging ideas and experiences, listening to the latest news from more advanced - maybe avant-garde museums - provides the staffs of small museums with a great opportunity to update their knowledge and esta- blish valuable contacts with colleagues. Both the central administration of the Nordic countries and some local communities provided economic support for the project. As the festival is regarded as a great success, one can only hope that next time, in Stavanger in the year 2000, public funding will be even more generous. The arrangement deserves support as it is important to everyone who regards museums and museum work as worth developing further in the future.

Ase Enerstvedt er free-lance fagbokforfatter med magistergrad i etnologi. Har vart museumsarbeider siden 1960-tallet - bestyrer for Hordamuseet $i$ Bergen fra 1975 til 1996. Sarlig interessert $i$ museenes maite à formidle kunnskap til barn - har utgitt boka "Barn, unge - museum" om norske formidlingsprosjekter og "Nordens barn - nordisk lys» en rapport om et nordisk kunstformidlingsprosjekt.

Adr: Drammensveien 975, 1370 Asker.

E-post: ase.enerstvedt@eunet.no 